\title{
ESTIMATION OF CLIMATE CHANGE IMPACT ON WATER RESOURCES BY USING BILAN WATER BALANCE MODEL
}

\author{
Stanislav Horacek, Ladislav Kasparek, Oldrich Novicky \\ T. G. Masaryk Water Research Institute \\ Prague, Czech Republic \\ stanislav_horacek@vuv.cz
}

\begin{abstract}
Modelling of water balance under changed climate conditions has been carried out by T. G. Masaryk Water Research Institute in Prague for basins in the Czech Republic since 1990. The studies presently use climate change scenarios derived from simulations by regional climate models. Climate change scenarios are reflected in meteorological time-series for given catchment and subsequently used for simulation of water cycle components by using Bilan water balance model.

The Bilan model can be used for assessing water balance components of a catchment in monthly or daily step. The model simulates water budget at three vertical levels. Three water balance algorithms that are applied were developed for winter conditions, snow melting and summer conditions. Excess water forms direct runoff or infiltrates to deeper zones, where it is divided into interflow and groundwater recharge. Results of Bilan model simulations for input meteorological series not affected and affected by climate change scenarios give information for assessing the climate change impacts on output series of the model.

The results of the studies generally show that annual runoff could largely decrease. The increased winter temperature could cause an increase in winter outflows and a decrease in snow storage, and consequently, spring and summer outflows will decrease significantly, even to their current minimum values. The groundwater storage and base flow could also be highly reduced.

The described method has been used in a number of research projects and operational applications. Its typical application is aimed at assessing possible impacts of climate change on surface water resources, whose availability can subsequently be analysed by water management studies of the individual basins. The Bilan model, particularly in combination with Modflow model, can also suitably be used for simulation and assessments of groundwater resources.
\end{abstract}

Keywords: water balance, climate change, hydrological model, Bilan model, water resources.

\section{INTRODUCTION}

Estimation of climate change impact in basins of the Czech Republic supports water management planning at different levels: central planning for whole republic area carried out by Ministry of Agriculture, planning at regional scale and water management of particular subjects applying for withdrawals of surface water or groundwater. The estimation can be performed by using methodology developed by T. G. Masaryk Water Research Institute in Prague. This methodology is based on water balance modelling by using Bilan water balance model under changed climate conditions. The paper describes principles of the methodology, presents results of a 
study which compares changes in outflows from basins in the Czech Republic and shows an example of typical application on assessing surface water availability.

\section{CLIMATE CHANGE SCENARIOS}

Climate change scenarios are used for deriving meteorological time-series. Presently, computing the affected time-series is based on results of regional climate models (RCM), which replaced an older approach based on using global climate models (GCM). The RCM results are provided by PRUDENCE project and are available for two scenarios of greenhouse gases emissions, which reflected possible alternatives of human socioeconomic progress. The emissions scenario SRES A2 assumes growth of emissions permanently, the scenario SRES B2 includes a decrease in emissions during this century.

The results of two models, HIRHAM and RCAO, were selected. HIRHAM model was developed by meteorological institutes of 8 European states and it is based on ECHAM model results, which is GCM provided by Max-Planck Institute in Hamburg. RCAO model was developed at Rossby Centre in Sweden and is composed from its atmospheric and oceanic part. All of the results are computed for period 2071-2100 (time horizon in year 2085) with reference time period 1960-1990.

Climate change scenarios based on these results were derived by Faculty of Mathematics and Physics of Charles University in Prague. They were prepared in the form of monthly time series of absolute changes in values of air temperature and dew-point temperature and relative changes in precipitation (Kalvová, 2005). Space resolution of used regional models is about $50 \times 50 \mathrm{~km}$, hence there are about 50 points in the area of the Czech Republic.

\section{METHODS FOR ASSESSING CLIMATE CHANGE IMPACT}

The impact of climate change on water resources is studied in given catchments by using Bilan model, which is lumped water balance model developed by T. G. Masaryk Water Research Institute (described in Tallaksen and van Lanen, 2004). This model can be used for assessing water balance components in monthly or daily step. The catchment is schematized as a system, whose inputs are basin precipitation, air temperature and relative air humidity (which both influence the evapotranspiration) and its output is the total streamflow.

The model simulates water budget at three vertical levels: on land surface, in soil layer and in groundwater aquifer. Three water balance algorithms that are applied were developed for winter conditions, snow melting and summer conditions. Surface water balance depends on evapotranspiration, which is determined by meteorological conditions using empirical values for different climate zones. Excess water forms direct runoff or infiltrates to deeper zone, where it is divided into interflow and groundwater recharge. Parameters of the model are determined by two-step optimization base on the deviations between observed and simulated river flows. Parameters significantly affecting total runoff are calibrating in the first step, the remaining parameters that affect distribution of the runoff into its components are optimized in the second step. The calibration by using base flow measurement can be alternatively applied. 


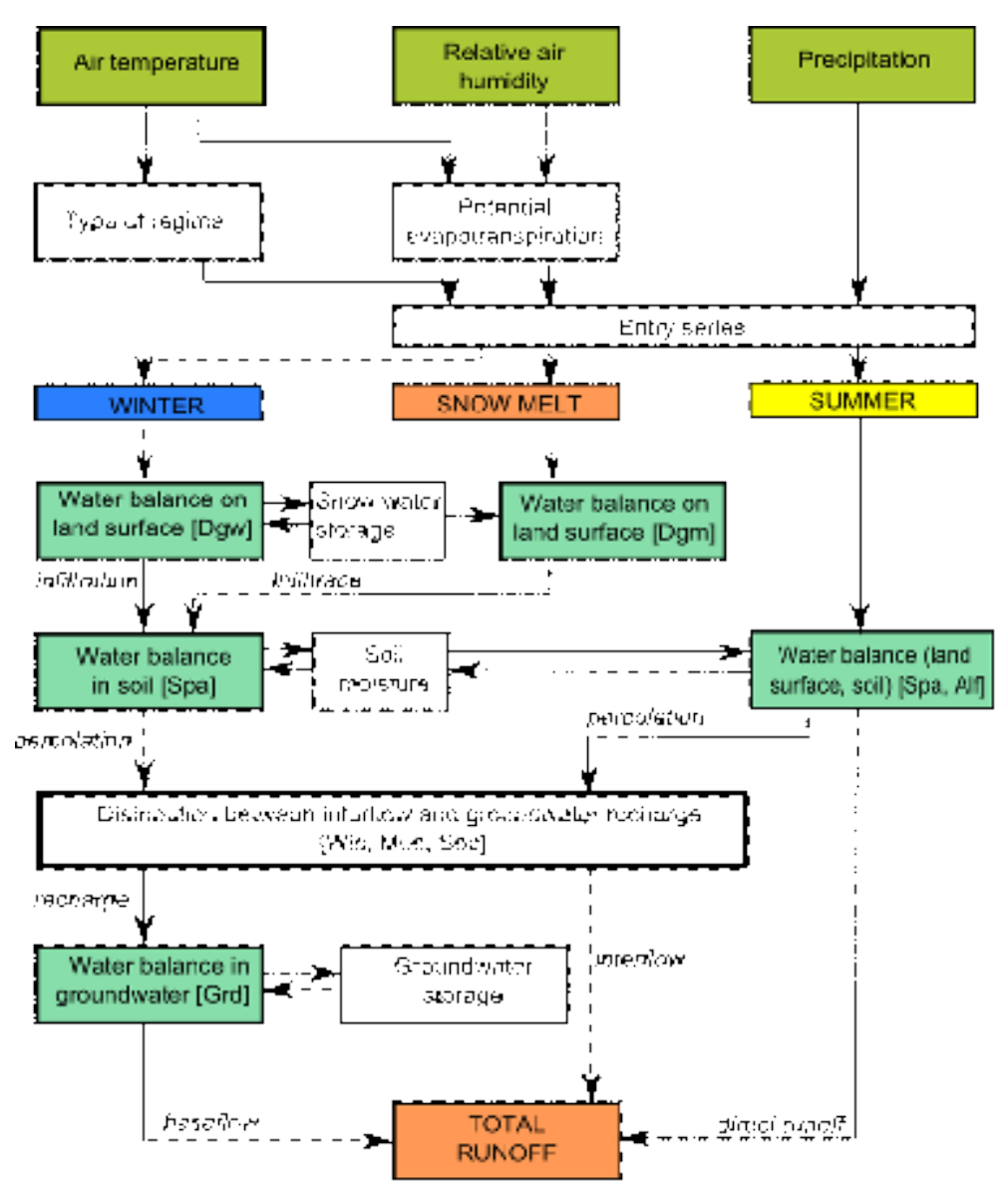

Figure 1. The scheme of Bilan water balance model

The estimation of climate change impact is based on knowledge of the model parameters calibrated for observed input series of meteorological variables and runoff values. These parameters are used in combination with the input meteorological series which have been modified for given climate change scenario.

The changes in meteorological variables for given catchment are derived from the values simulated by RCM for points, which are located within the catchment area and in its surroundings. The derivation uses inverse distance weighting method based on distances of the points from the centre of the catchmen. Precipitation and air temperature time-series are accordingly modified by adding the interpolated values. Relative humidity is calculated from interpolated dew-point temperature.

Results of simulations for affected and not affected input series give information for assessing the climate change impacts on output series of the model, which include potential evapotranspiration, basin evaporation, three components of river flow (surface runoff, interflow and base flow), groundwater recharge and three components of water storage (in snow cover, soil layer and groundwater aquifer).

\section{CHANGES IN METEOROLOGICAL VARIABLES}

Generally, annual variability of changes in meteorological values resulting from RCM is more important than spatial variability across the area of the Czech Republic. HIRHAM model predictions are highly influenced by local orography, there is a significant dependency between climate changes values and altitude of given 
location. Opposed to this, RCAO model puts the accent on simulation of air circulation between ocean and continent and its resulting changes of meteorological variables correspond with east-west gradient across the Czech Republic.

Precipitation is the most important variable in the water balance assessment. Its change in terms of annual means due to climate change is negligible but its seasonality changes - winter precipitation increases (especially in February, depending on climate model, scenario and locality) from 10 to $60 \%$ (Figure 2) and summer precipitation decreases, which is significant especially in August (the decrease from 5 to $50 \%$ ). HIRHAM predicts the most important winter increase and summer decrease in the northern Bohemia and in the eastern Moravia, RCAO assumes the most variable precipitation in the region of southern Moravia. Influence of emission scenario is more important than climate model influence, models using scenario SRES B2 predict higher precipitation.
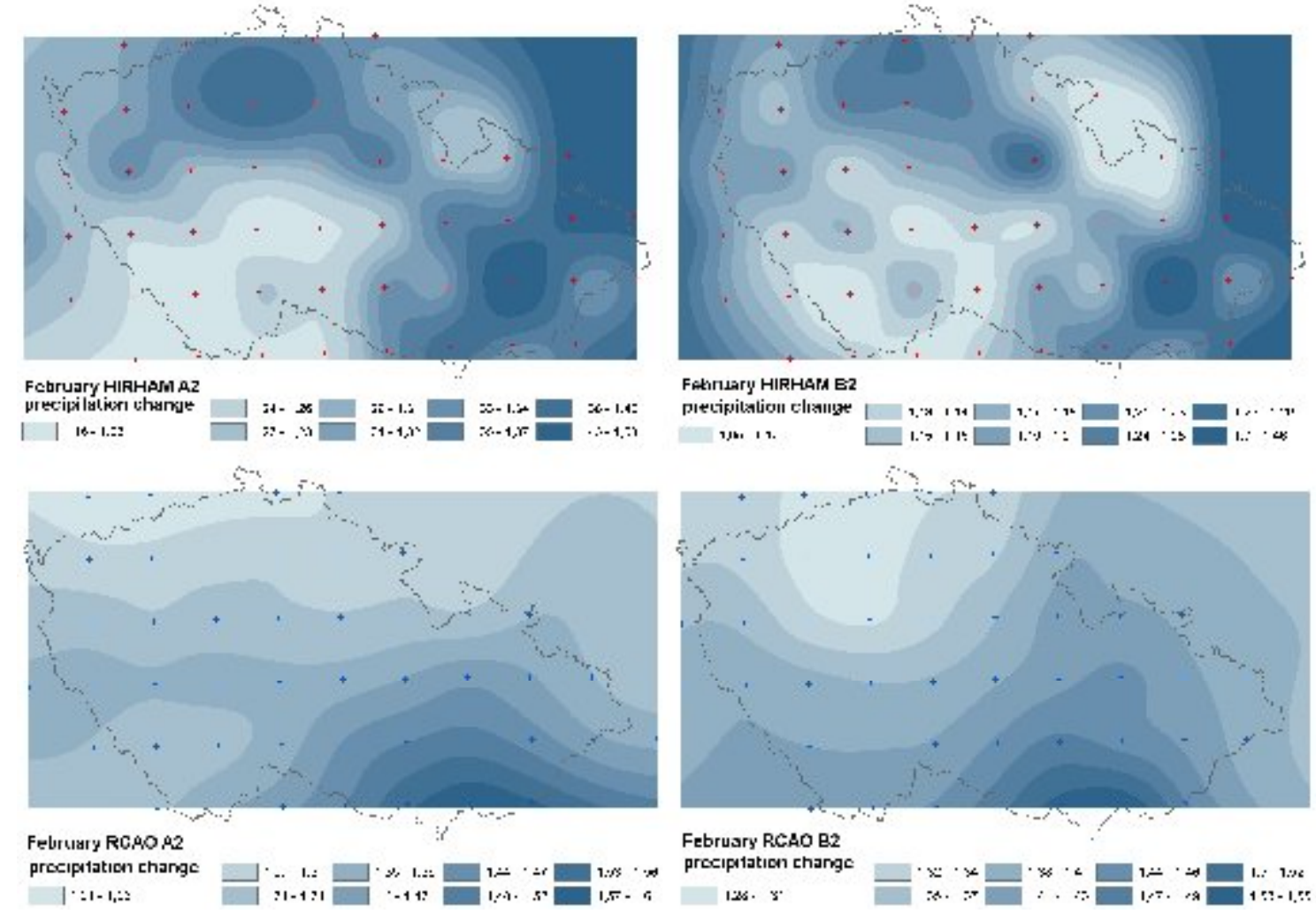

Figure 2. Change in precipitation in February according to the used climate model and emission scenario

Both models predict significant temperature increase for all months, the changes range from 3 to $8{ }^{\circ} \mathrm{C}$ for $\mathrm{A} 2$ emission scenario and from 1 to $6{ }^{\circ} \mathrm{C}$ for $\mathrm{B} 2$ emission scenario, RCAO model expects lower changes than HIRHAM. Temperature changes in August are shown in Figure 3. Temperature seasonality simulated by HIRHAM can be divided into two intervals. The first of them, from April to September, is characteristic by higher changes in lowland regions, during the second part of the year, higher changes are predicted in mountains. According to longitude dependency of RCAO, temperature changes are higher in the eastern part of the Czech Republic than in the western part. 


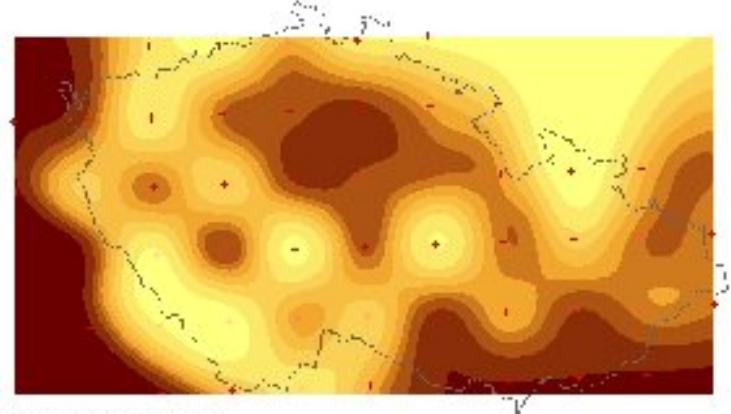

AuguSt HIRHAM A2

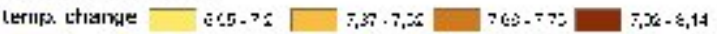

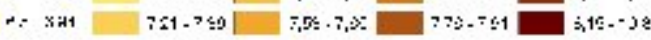
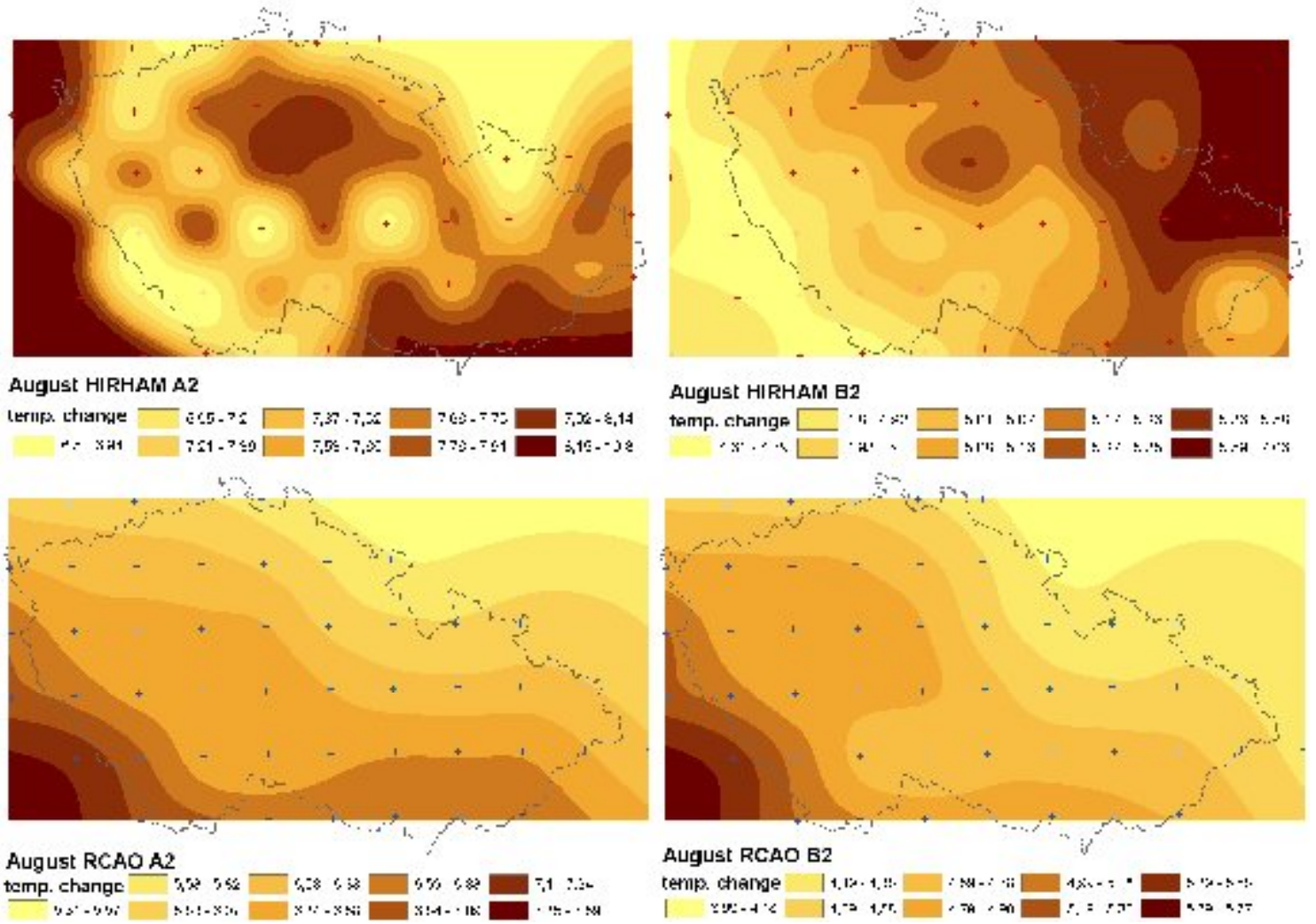

August RCAO A2 temp. change

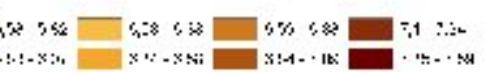

termp. change $1,1,1,1, !$.

Figure 3. Change in the air temperature in August according to the used climate model and emission scenario

\section{CHANGES IN RUNOFF IN BASINS OF THE CZECH REPUBLIC}

Climate change impact on water resources was studied in monthly time step for Czech parts of Elbe and Danube basin (Kašpárek, 2006). Four variants of regional scenarios were used. They include two types of climate models and two types of emission scenarios.

Bilan model calculations were based on data series from the period 1932-2003, which were provided by the Czech Hydrometeorological Institute. The Bilan model was calibrated and subsequent simulations were performed for 61 basins from the whole area of the Czech Republic.

The results showed that the main impact of the climate change is the decrease in mean annual runoff in all of the basins except several basins in the southern Bohemia and southern Moravia under conditions of SRES B2 emission scenario. The mean of the simulated annual runoff for all basins is $67 \%$ of the simulated unaffected runoff for HIRHAM model and A2 scenario, $80 \%$ for both HIRHAM B2 and RCAO A2 alternatives and $92 \%$ for RCAO model and B2 scenario. 


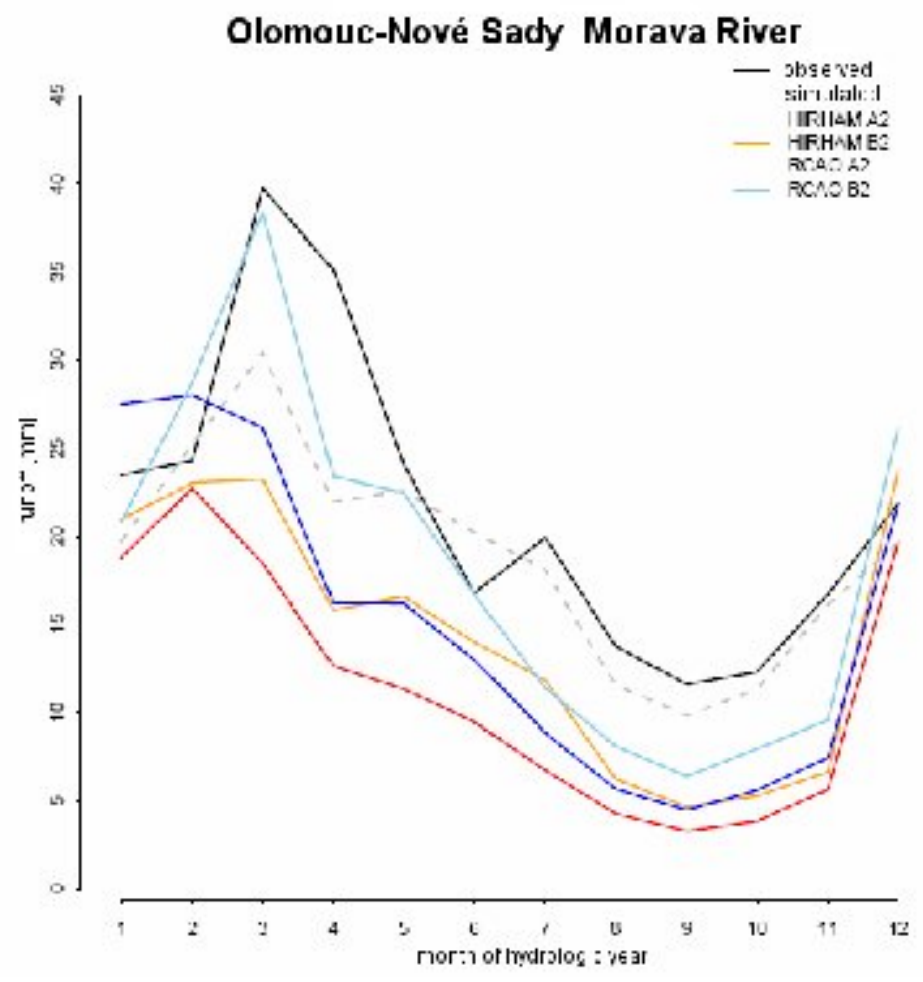

Figure 4. Example of typical seasonal patterns of total runoff - mean values of unaffected and affected runoff

For most of the months the runoff also decreases, except for winter period from December to February when outflows increase or only moderately decrease. This is caused by higher winter temperature (monthly temperature below zero is predicted only for December), which is reflected in an increase in runoff and a decrease in snow storage. Consequently, spring and summer outflows decrease significantly in some basins, even to their current minimum values. An example of typical annual runoff distribution is shown in Figure 4. The groundwater storage and base flow could also be highly reduced. For detailed studies focused on groundwater, it is possible to use groundwater recharges simulated by Bilan as an input to Modflow model.

There is high spatial variability in affected runoff, the changes can be different even in the same region. However, there is a trend to smaller decrease in the northern Bohemia (basins of the Upper Elbe and Ohře River). Spatial variability in runoff changes for different models and scenarios is shown in Figure 5. 

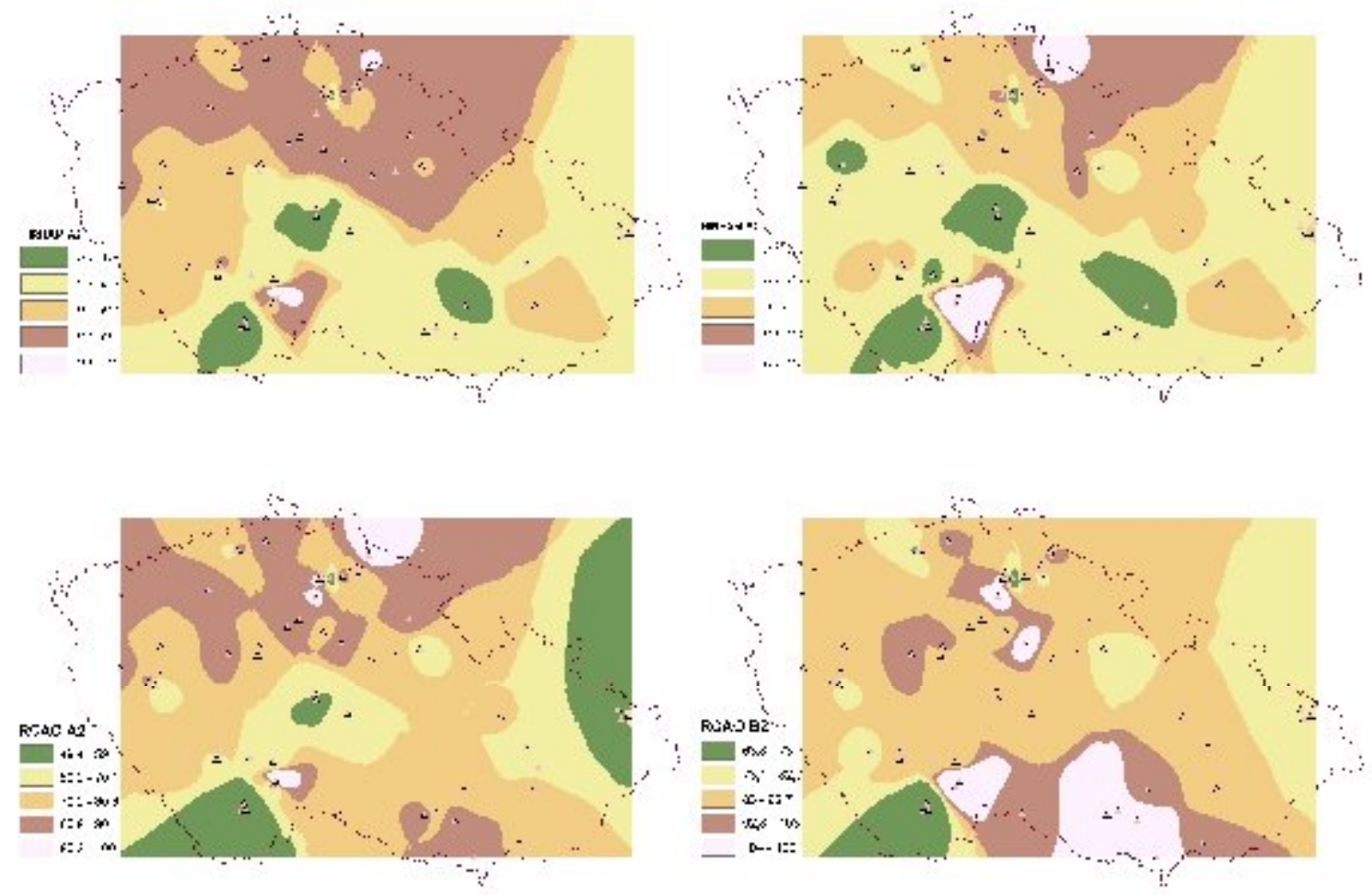

Figure 5. Change in mean annual runoff according to the used climate model and emission scenario

\section{A CASE STUDY: ESTIMATION OF CLIMATE CHANGE IMPACT ON WATER AVAILABILITY FOR A POWER PLANT}

The described method has been used in a number of applications. Its typical application is aimed at assessing possible impacts of climate change on surface water resources, whose availability can subsequently be analysed by water management studies of the individual basins and studies of capacities and functions of reservoirs in the basin.

One of these studies was focused on availability of industrial water for Temelín Nuclear Power Plant (Kašpárek, 2007), which is located in the southern Bohemia. Water balance was assessed for three subbasins of the Vltava River (including the reservoir used for the withdrawals) and for two basins of its tributaries. Time-series with length of 44 years were used. The runoff simulations for observed meteorological data were compared with simulations for climate change scenarios. The first scenarios were based on RCM model simulations and related to time horizon of 2085, the second scenarios represented short-term outlook for year 2020, which was based on current trends of meteorological variables. Reduction of outflows due to climate change ranged from 5 to $25 \%$ for 2020 or from 5 to $65 \%$ for 2085 (depending on basin and RCM or emission scenario type). In the season from November to March, monthly runoff was highly variable with higher mean than that of the runoff in the second season, whose variability was smaller. This distribution reflects the change in precipitation seasonality and earlier snow melting consequently to the increased winter temperature. 
The results of hydrological part of the study were used as input to model of water management system. This model was applied for estimation of water supply reliability, which was calculated as minimum monthly ratio between available volume of water and that stemming from the supply requirements. The reliability was $100 \%$ for all of the scenarios for 2020 and for SRES B2 scenarios for 2085. For SRES A2 scenarios for time horizon of 2085 , the resulting reliability was $40 \%$ for HIRHAM model and $76 \%$ for RCAO model. In these cases, maximum duration of the failure period was 3 months and 5 months respectively.

\section{CONCLUSIONS}

The lumped hydrologic water balance model (Bilan), represented as a system of storages and flows at three vertical levels, can be used for estimation of climate change impact on hydrologic cycle and its components. The results of the simulation by regional climate change models provide suitable base for derivation of necessary meteorological data. The described method was applied for general studies of large basins as well as for detailed studies aimed at supporting the activities in water management planning. The results of these studies show that mean annual runoff and monthly runoff in spring, summer and autumn can significantly decrease consequently to climate change. These impacts can be reflected in a risk of insufficiency of the existing retention capacities in water resources for meeting the water supply requirements in future.

\section{References}

Kalvová, J. et al. (2005): Vytvoření klimatických scénářů pro ČR (Preparation of climate scenarios for the CR), In: Research and protection of hydrosphere, Research project of Ministry of the Environment no. 0002071101, Part A. Hydrology. Research report. VúV T.G.M., Prague; 22-46.

Kašpárek, L. et al. (2006): Dopad klimatické změny na Českou republiku podle regionálních klimatických scénárư (Climate change impact estimation in the Czech Republic by using regional climate scenarios). In: Research and protection of hydrosphere, Research project of Ministry of the Environment no. 0002071101, Part A. Hydrology. Research report. VúV T.G.M., Prague; 90-105.

Kašpárek, L. et al. (2007): Studie možnosti zajištění odběrů vody z VD Hněvkovice pro výhledové rozšiření JE Temelín (Possibilities of water supply from Hněvkovice reservoir for future production of Temelín Nuclear Power Plant). VúV T. G. M., Prague.

Tallaksen, L. M., van Lanen, H. A. J. (editors) (2004): Hydrological Drought - Processes and Estimation Methods for Streamflow and Groundwater. Developments in Water Science 48, Elsevier B.V., Amsterdam. 